\title{
Correction to: Total knee replacement in Osteogenesis Imperfecta: a case report and review of the literature
}

Allan Roy Sekeitto ${ }^{*}$, Kaeriann van der Jagt, Nkhodiseni Sikhauli and Dick Ronald van der Jagt

Correction to: Arthroplasty 3, 4 (2021)

https://doi.org/10.1186/s42836-020-00061-5

Following publication of the original article [1], the authors reported an error for some numbers in the sentence "her visual analogue score (VAS) was 3/10, 7/10 and $8 / 10$ before, 6 and 24 months after surgery respectively" in the Case report section.

The numbers should be corrected into " $7 / 10,3 / 10$ and $2 / 10$ ".

The original article [1] has been updated.

Published online: 11 May 2021

\section{Reference}

1. Sekeitto AR, van der Jagt K, Sikhauli N, van der Jagt DR. Total knee replacement in Osteogenesis Imperfecta: a case report and review of the literature. Arthroplasty. 2021;3(1):4. https://doi.org/10.1186/s42836-02000061-5.

*Correspondence: sekeitto@yahoo.com

Arthroplasty Unit, Division of Orthopaedic Surgery, Charlotte Maxeke

Johannesburg Academic Hospital, University of the Witwatersrand, 7 York Road, Parktown, Johannesburg, South Africa

(c) The Author(s). 2021 Open Access This article is licensed under a Creative Commons Attribution 4.0 International License, which permits use, sharing, adaptation, distribution and reproduction in any medium or format, as long as you give appropriate credit to the original author(s) and the source, provide a link to the Creative Commons licence, and indicate if changes were made. The images or other third party material in this article are included in the article's Creative Commons licence, unless indicated otherwise in a credit line to the material. If material is not included in the article's Creative Commons licence and your intended use is not permitted by statutory regulation or exceeds the permitted use, you will need to obtain permission directly from the copyright holder. To view a copy of this licence, visit http://creativecommons.org/licenses/by/4.0/ 